\title{
MODEL PEMESANAN BAHAN BAKU MENGGUNAKAN PERAMALAN TIME SERIES DENGAN CB PREDICTOR
}

\author{
Tri Pujadi \\ Information System Department, School of Information System, BINUS University \\ Jln. K.H. Syahdan No. 9, Palmerah, Jakarta Barat 11480 \\ tripujadi@binus.edu
}

\begin{abstract}
A company that manufactures finished goods often faces a shortage of raw materials, due to the determination of the quantity of raw material ordering improper because it is done by intuition and the lack of raw material inventory reserves. This resulted in costs because inefficient production processes are inhibited or had to perform an emergency procurement of raw materials to meet customer orders. The company seeks to use the method in determining the order quantity of raw material, comprising the steps of (1) collecting historical data of raw material use, step (2) forecasting needs raw materials, step (3) calculating the order quantity forecasting based on the data by comparing the deterministic method and probabilistic methods. Calculating safety stock for each raw material is done so as to cope with the situation outside of normal conditions, such a surge in orders. In its design, the system will be developed using the Unified Modeling Language modeling language (UML) on the basis of the concept of object-oriented analysis and design (Object Oriented Analysis and Design). With the proposed implementation of the information system, the company can estimate the need for raw materials more quickly and accurately, and can determine the order quantity that is tailored to the needs. So that the costs associated with ordering and storage of raw materials can be minimized.
\end{abstract}

Keywords: forecasting, inventory, deterministic methods, safety stock

\begin{abstract}
ABSTRAK
Sebuah perusahaan manufaktur kerap kali menghadapi kekurangan bahan baku yang disebabkan kuantitas pemesanan bahan baku yang tidak akurat dan tidak adanya persediaan bahan baku cadangan. Persoalan ini berakibat biaya yang tidak efisien karena proses produksi yang terhambat ataupun harus melakukan pengadaan bahan baku darurat untuk memenuhi pesanan pelanggan. Solusi yang dibuat untuk mengatasi persoalan ini adalah perlunya dikembangkan sebuah sistem berbasis teknologi (web) yang mendukung pemesanan bahan baku; dan dengan melihat sifat dari bahan baku yang akan dilakukan pembeliannya, maka perhitungan dilakukan berdasarkan peramalan time-series dengan CB-Predictor. Adapun metodologi dalam perhitunganya adalah (1) mengumpulkan data historis penggunaan bahan baku, langkah (2) peramalan kebutuhan bahan baku, langkah (3) menghitung kuantitas pemesanan berdasarkan data peramalan, dengan membandingkan metode deterministik dan metode probabilistik. Selanjutnya dilakukan penghitungan safety stock untuk tiap bahan baku sehingga dapat mengatasi situasi di luar kondisi normal, seperti lonjakan order. Dalam perancangannya, sistem yang akan dikembangkan menggunakan bahasa pemodelan Unified Modeling Language(UML) dengan berbasiskan konsep analisis dan perancangan berorientasi objek (Object Oriented Analysis and Design). Hasilnya adalah model aplikasi sistem berbasis teknologi (web) yang dapat mendukung perhitungan pemesanan bahan baku lebih efisien dan akurat. Dengan usulan penerapan sistem informasi, maka perusahaan dapat memperkirakan kebutuhan bahan baku dengan lebih cepat dan cermat, serta dapat menentukan kuantitas pemesanan yang disesuaikan dengan kebutuhan. Dengan demikian, biaya-biaya yang berhubungan dengan pemesanan dan penyimpanan bahan baku dapat diminimalkan.
\end{abstract}

Kata kunci: peramalan, persediaan, metode deterministik, safety stock, OOAD 


\section{PENDAHULUAN}

Faktor penting yang berpengaruh dalam melayani pelanggan adalah ketersediaan barang produksi. Untuk hal itu, maka diperlukan pemesanan bahan baku untuk produksi dalam jumlah yang tepat. Apabila bahan baku dapat dipesan dalam kuantitas dan waktu yang mencukupi, proses produksi dapat berjalan dengan lancar karena bahan baku selalu tersedia. Ditambah lagi, biaya-biaya yang berhubungan dengan persediaan juga dapat diminimalkan, seperti biaya pesan, biaya simpan, dan biaya backorder.

Kekurangan bahan baku dapat merugikan perusahaan. Hal itu dapat menghambat proses produksi, memperbesar biaya pesan karena sering kali harus melakukan pemesanan bahan baku, menurunkan kepercayaan di mata pelanggan, dan harus membayar biaya backorder, yaitu biaya penalti karena tidak dapat memenuhi pesanan pelanggan tepat waktu.

Ketepatan waktu harus dapat diukur secara benar oleh perusahaan dari awal pesanan dicatat, pesanan diproduksi, sampai pesanan dikirimkan kepada pelanggan. Faktor penting yang mendukung ketepatan waktu tersebut adalah pemesanan kuantitas bahan baku yang tepat dan waktu untuk melakukan pemesanan bahan baku tersebut. Apabila bahan baku dapat dipesan dalam kuantitas dan waktu yang tepat, proses produksi dapat berjalan dengan lancar karena bahan baku selalu tersedia. Biaya-biaya yang berhubungan dengan persediaan juga dapat diminimalkan, seperti biaya pesan, biaya simpan dan biaya backorder.

Oleh karena itu, suatu sistem informasi pengendalian bahan baku yang dapat membantu dalam mengatur dan mengelola stok bahan baku secara cepat dan tepat diperlukan. Dengan demikian, perusahaan akan dapat memenuhi pesanan pelanggan tepat waktu serta dapat menjaga kredibilitas dan kepercayaan di mata pelanggan. Adapun tujuan dilakukannya pembuatan model pemesanan ini antara lain: (1) membuat perencanaan yang tepat mengenai peramalan kebutuhan bahan baku sesuai dengan data historis produksi; (2) memberikan usulan mengenai metode pemesanan bahan baku dengan kuantitas yang tepat, dengan memperhitungkan perbandingan biaya penyimpanan dan biaya pemesanan bahan baku. Serta memberikan usulan kapan harus melakukan pemesanan bahan baku kembali, sesuai dengan peramalan kebutuhan bahan baku yang telah dilakukan sebelumnya; (3) membuat usulan mengenai kuantitas safety stock dari masing-masing jenis bahan baku; (4) mengusulkan sebuah model sistem informasi untuk mendukung proses pencatatan stok bahan baku yang keluar maupun yang diterima, perhitungan peramalan kebutuhan bahan baku, dan perhitungan kuantitas pemesanan bahan baku.

Hasil penerapan model sistem yang telah dibuat, diharapkan akan menimbulkan manfaat bagi perusahaan dalam upaya-upaya: (a) meningkatkan akurasi penentuan kebutuhan bahan baku di periode mendatang; (b) meningkatkan akurasi pencatatan stok bahan baku di gudang; (c) meningkatkan akurasi penentuan kuantitas pemesanan bahan baku; (d) meminimasi biaya penyimpanan dan biaya pemesanan bahan baku; (e) meningkatkan efesiensi pekerjaan karyawan bagian gudang bahan baku dan bagian pembelian karena dengan adanya sistem maka mereka dapat bekerja lebih cepat; (f) membantu bagian gudang untuk melakukan perhitungan kebutuhan bahan baku untuk setiap pesanan (order) yang masuk; (g) meningkatkan kepuasan pelanggan dengan memberikan ketepatan waktu pengiriman pesanan (order); (h) meningkatkan kredibilitas perusahaan di mata pelanggan.

\section{Persediaan}

Menurut Baroto (2002:52), persediaan adalah bahan mentah, barang dalam proses (work in process), barang jadi, bahan pembantu, bahan pelengkap, komponen yang disimpan dalam antisipasinya terhadap pemenuhan permintaan. Pengendalian persediaan merupakan fungsi manajerial yang sangat penting, karena mayoritas perusahaan melibatkan investasi besar pada aspek ini (20\% 
sampai 60\%). Hal tersebut merupakan dilema bagi perusahaan. Bila persediaan dilebihkan, biaya penyimpanan dan modal yang diperlukan bertambah. Kelebihan persediaan juga membuat modal menjadi mandek, semestinya modal tersebut dapat diinvestasikan pada sektor lain yang lebih menguntungkan (opportunity cost). Sebaliknya bila persediaan dikurangi, maka dapat terjadi kehabisan bahan baku (stock out). Bila perusahaan tidak memiliki persediaan yang mencukupi, biaya pengadaan darurat akan lebih mahal, dampak lainnya adalah kekecewaan konsumen terhadap perusahaan.

Metode pemesanan bahan baku seperti Gambar 1.

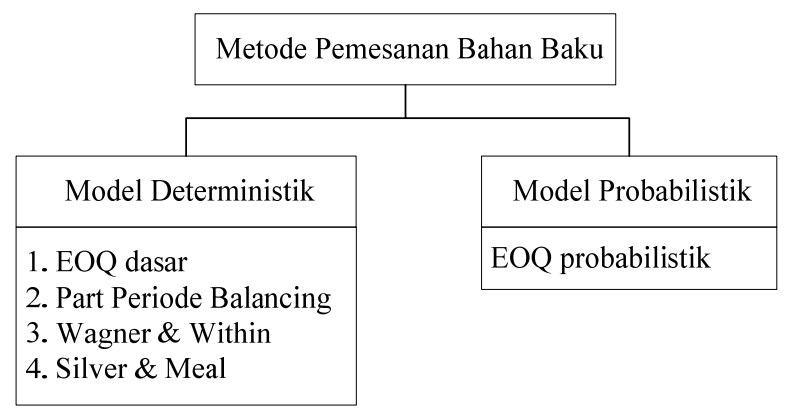

Gambar 1 Metode pemesanan bahan baku

Penentuan penggunaan metode pemesanan bahan baku disesuaikan dengan pola data demand. Pola data demand dibagi menjadi dua, yaitu: data statik, yaitu demand dengan pola data stasioner, atau cenderung konstan atau stabil; data dinamis, yaitu demand dengan pola data yang naik turun, atau cenderung bergerak, disebut juga dengan "lumpy demand".

\section{Pemesanan}

Menurut Griffiths dan Payab (2004), yang dimaksud pemesanan adalah pengadaan barang atau pembelian barang dan jasa untuk perusahaan yang telah diatur di dalam rantai supply chain mereka. Terdapat dua jenis pengadaan barang yaitu direct procurement dan indirect procurement. Hal ini dikaitkan dengan tujuan pengadaannya apakah untuk mendukung proses produksi (production related) ataukah non-production related. Melalui pengelolaan pengadaan yang baik akan diperoleh peningkatan layanan pemesanan yang pada gilirannya menghasilkan penghematan anggaran dan menyederhanakan proses pengadaananya sehingga akan lebih efisien.

Adapun Subramanian dan Shaw (2004) mengidentifikasikan terdapat tiga area yang akan didukung oleh pengadaan barang dan jasa yang dilakukan secara online (disebut e-procurement), yaitu dalam proses transaksi pemesanan, manajemen persediaan serta dukungan dalam pemasaran (marketmaking). Dengan demikian penggunaan e-procurement akan berdampak terhadap empat aktivitas B2B, yaitu: search and identifying of right product, order processing, monitoring and control, serta koordinasi di antara perusahaan dan partnernya

\section{Peramalan}

Menurut Makridakis et al. (1999) dan Mose et al (2013), peramalan (forecasting) merupakan prediksi nilai-nilai sebuah variabel berdasarkan kepada nilai yang diketahui dari variabel tersebut atau variabel yang berhubungan. Meramal juga dapat didasarkan pada keahlian penilaian, yang pada gilirannya didasarkan pada data historis dan pengalaman. Alasan utama dari peramalan adalah adanya waktu tenggang (lead time) antara kesadaran akan peristiwa atau kebutuhan mendatang dengan 
peristiwa itu sendiri. Jika waktu tenggang ini nol atau kecil, perencanaan dan peramalan tidak diperlukan. Sedangkan jika waktu tenggang panjang dan hasil peristiwa akhir bergantung pada faktorfaktor yang dapat diketahui, peramalan dibutuhkan untuk menetapkan kapan suatu peristiwa akan terjadi atau timbul, sehingga tidakan yang tepat dapat dilakukan.

Sedangkan Subramanian dan Shaw (2004:54) dan Render et al (2001:46) menyatakan bahwa peramalan adalah seni dan ilmu memprediksi peristiwa-peristiwa masa depan dengan beberapa bentuk model matematis, bisa berupa prediksi subjektif atau intuitif tentang masa depan atau bisa juga mencakup kombinasi model matematis yang disesuaikan dengan penilaian yang baik oleh manajer. Menurut Render et al (2001:46), peramalan biasanya dikelompokkan oleh horizon waktu masa depan yang mendasarinya, yaitu: (a) peramalan jangka pendek, biasanya digunakan untuk merencanakan pembelian, penjadwalan kerja, jumlah tenaga kerja, penugasan, dan tingkat produksi, dan rentang waktunya mencapai satu tahun tapi umumnya kurang dari tiga bulan; (b) peramalan jangka menengah, biasanya berjangka waktu tiga bulan hingga tiga tahun, dan sangat bermanfaat dalam perencanaan penjualan, perencanaan dan penganggaran produksi, penganggaran kas, dan menganalisis berbagai rencana operasi; (c) peramalan jangka panjang, biasanya memiliki rentang waktu tiga tahun atau lebih, dan digunakan dalam merencanakan produk baru, pengeluaran modal, lokasi fasilitas, atau ekspansi dan penelitian serta pengembangan.

\section{Peramalan Time Series dengan CB Predictor}

Dewasa ini, sudah banyak tersedia software yang mendukung perhitungan peramalan, sehingga user dapat lebih mudah untuk melakukan perhitungan peramalan tersebut. Menurut Griffiths dalam Siswanto (2007:314), salah satu jenis peranti lunak yang dapat mendukung perhitungan peramalan dengan mudah dan cepat adalah CB Predictor.

CB Predictor adalah sebuah program yang ada di dalam Crystal Ball. Program ini adalah program untuk memprediksi data yang akan terjadi di masa yang akan datang dengan menganalisis data masa lalu. Dalam gallery program ini, tersedia delapan model peramalan (forecasting model), yaitu: (a) Single Moving Average, adalah metode peramalan yang digunakan untuk data stasioner (tidak mengandung unsur musiman ataupun tren); (b) Double Moving Average, adalah metode peramalan yang digunakan untuk data yang mengandung unsur tren; (c) Single Exponential Smoothing, adalah metode peramalan yang digunakan untuk data stasioner (tidak mengandung unsur musiman ataupun tren); (d) Double Exponential Smoothing, adalah metode peramalan yang digunakan untuk data yang mengandung unsur tren; (e) Seasoanal Additive, adalah metode peramalan yang digunakan untuk data yang mengandung unsur musiman; (f) Holt Winter's Additive, adalah metode peramalan yang digunakan untuk data yang mengandung unsur musiman dan tren; (g) Seasonal Multiplicative, adalah metode peramalan yang digunakan untuk data yang mengandung unsur musiman. Metode ini merupakan metode yang paling baik untuk data dengan agregasi paling tinggi, seperti penjualan produk dan data kebutuhan bahan baku.

Perhitungan metode Seasonal Multiplicative dipengaruhi oleh $\alpha$ dan $\gamma$. Pertama kali yang harus dilakukan adalah menentukan unsur musiman n periode, untuk menentukan seasonal term-nya.

\section{Block Replacement}

Dalam block replacement, tindakan penggantian dilakukan pada suatu interval yang tetap. Cara ini diterapkan dengan melakukan penggantian kerusakan yang terjadi pada interval $\left(0, t_{p}\right)$ dengan mengabaikan adanya penggantian yang terjadi selama selang waktu tersebut, serta melakukan penggantian pencegahan pada setiap selang waktu $t_{p}$ secara konstan (Vaidya et al, 2006:95).

Block replacement memungkinkan terjadinya penggantian dalam kurun waktu yang berdekatan. Komponen yang baru dipasang setelah penggantian kerusakan harus mengalami penggantian kembali pada saat tiba waktu penggantian pencegahan $\left(\mathrm{t}_{\mathrm{p}}\right)$. 


$D\left(t_{p}\right)=\frac{\text { Ekspektasi downtime kerusakan+donwtime penggantian pencegahan }}{\text { panjang siklus }}$
\[ D\left(t_{p}\right)=\frac{\left(\mathrm{H}\left(t_{p}\right) T_{f}\right)+\mathrm{T}_{p}}{t_{p}+\mathrm{T}_{p}} \]
dimana :
$t_{p} \quad=$ interval waktu penggantian pencegahan
$\mathrm{D}\left(t_{p}\right) \quad=$ downtime persatuan waktu
$\mathrm{H}\left(t_{p}\right) \quad=$ ekspektasi jumlah kerusakan pada interval $(0, \mathrm{t})$
$\mathrm{T}_{f} \quad=$ downtime yang terjadi karena penggantian kerusakan
$\mathrm{T}_{p} \quad=$ downtime yang terjadi karena penggantian pencegahan

\section{METODE}

Metode dalam perhitungan untuk peramalan dan persediaan bahan baku dilakukan melalui langkah-langkah sebagai berikut. Pertama, dari data penggunaan bahan baku selama tiga tahun terakhir, kemudian dilakukan peramalan kebutuhan bahan baku untuk dua belas periode berikutnya dengan menggunakan bantuan piranti lunak, yaitu CB Predictor. Kedua, dari beberapa hasil peramalan untuk setiap jenis bahan baku, dipilih metode peramalan dengan nilai presentase error (MAPE $\rightarrow$ Mean Absolute Percentage Error) paling kecil. Ketiga, setelah ditentukan hasil peramalan sesuai dengan metode yang memiliki tingkat kesalahan paling kecil, maka dilakukan perhitungan Variability Coefficient (VC).

Perhitungan VC adalah perhitungan koefisien dari hasil perhitungan peramalan untuk menentukan metode deterministik untuk perhitungan kuantitas pemesanan bahan baku. Jika VC lebih kecil dari 0.25, kebutuhan bahan baku tiap bulannya stabil, dan untuk menentukan kuantitas pemesanan bahan baku cukup digunakan metode EOQ (Economic Order Quantity). Sedangkan bila VC lebih besar dari 0.25, kebutuhan bahan baku tiap bulan tidak stabil: ada kalanya naik dan ada kalanya turun, sehingga untuk menentukan kuantitas pemesanan harus menggunakan perbandingan beberapa metode, yaitu metode Silver \& Meal (S\&M), Wagner \& Within (W\&W), dan Part Periode Balancing (PPB).

Adapun metode pengembangan sistem untuk membuat model pemesanan bahan baku mengacu pada pengembangan sistem informasi berbasis objek dengan menggunakan artifdact Unified Model Language (UML) dengan langkah-langkah sebagai berikut. Kegiatan diawali dengan melakukan analisis sistem informasi yang sedang berjalan. Analisis sistem berjalan ini dimaksudkan untuk mengetahui kebutuhan informasi user dan interaksi user dengan fungsi sistem yang ada, sehingga dapat dijadikan patokan untuk diusulkan perbaikan sistem ke arah yang lebih baik dalam hal ketersediaan informasi maupun fungsi dari sistem itu sendiri. (a) Analisis Problem Domain; dalam analisis problem domain, akan didapatkan informasi mengenai objek apa saja yang terlibat dalam sistem dan aktivitasyang berhubungan dengan objek tersebut. Objek dan aktivitas ini selanjutnya akan digambarkan dalam bentukactivity diagram. (b) Analisis Application Domain; dalam analisis application domain, akan dirancang fungsi sistem yang disesuaikan dengan problem domain sebelumnya. Langkah-langkah dalam analisis application domain antara lain: membuat class diagram yang menjelaskan hubungan antar-class dan attribute dan membuat use case dan menentukan actor untuk menghasilkan usecase diagram dengan tujuan untuk mengenali interaksi actor dalam suatu sistem. (c) Analisis User Interface; merancang sebuah user interface berarti merancang suatu keterlibatan antara input dan output ketika user berinteraksi dengan komputer untuk melaksanakan tugas. Seorang pengembang harus mempertimbangkan interaksi antara user dan komputer untuk memproses hasil input maupun output. 


\section{HASIL DAN PEMBAHASAN}

\section{Proses Bisnis Pengadaan Bahan Baku}

Saat ini, perusahaan belum memiliki sistem pemesanan bahan baku terkomputerisasi. Semua hal yang berkaitan dengan pencatatan persediaan bahan baku dan pemesanan bahan baku dilakukan secara manual, baik dengan menggunakan kata-kata, maupun secarik kertas. Pesanan pelanggan diterima oleh bagian pemasaran, kemudian bagian pemasaran membuat Sales Order sebanyak tiga rangkap. Rangkap satu disimpan oleh bagian pemasaran sebagai dokumentasi, dan rangkap dua dikirim kepada bagian produksi dan rangkap tiga diberikan kepada bagian gudang barang jadi.

Setelah menerima Sales Order, manajer produksi kemudian membuat Job Order sebanyak tiga rangkap. Rangkap satu untuk disimpan sebagai dokumentasi, rangkap dua diberikan kepada bagian gudang bahan baku, dan rangkap tiga diberikan kepada bagian lantai produksi. Kemudian bagian gudang bahan baku menyiapkan bahan baku yang dibutuhkan dalam job order dan kepala gudang mencatat bahan baku apa saja yang dikeluarkan dari gudang bahan baku. (Gambar 2)

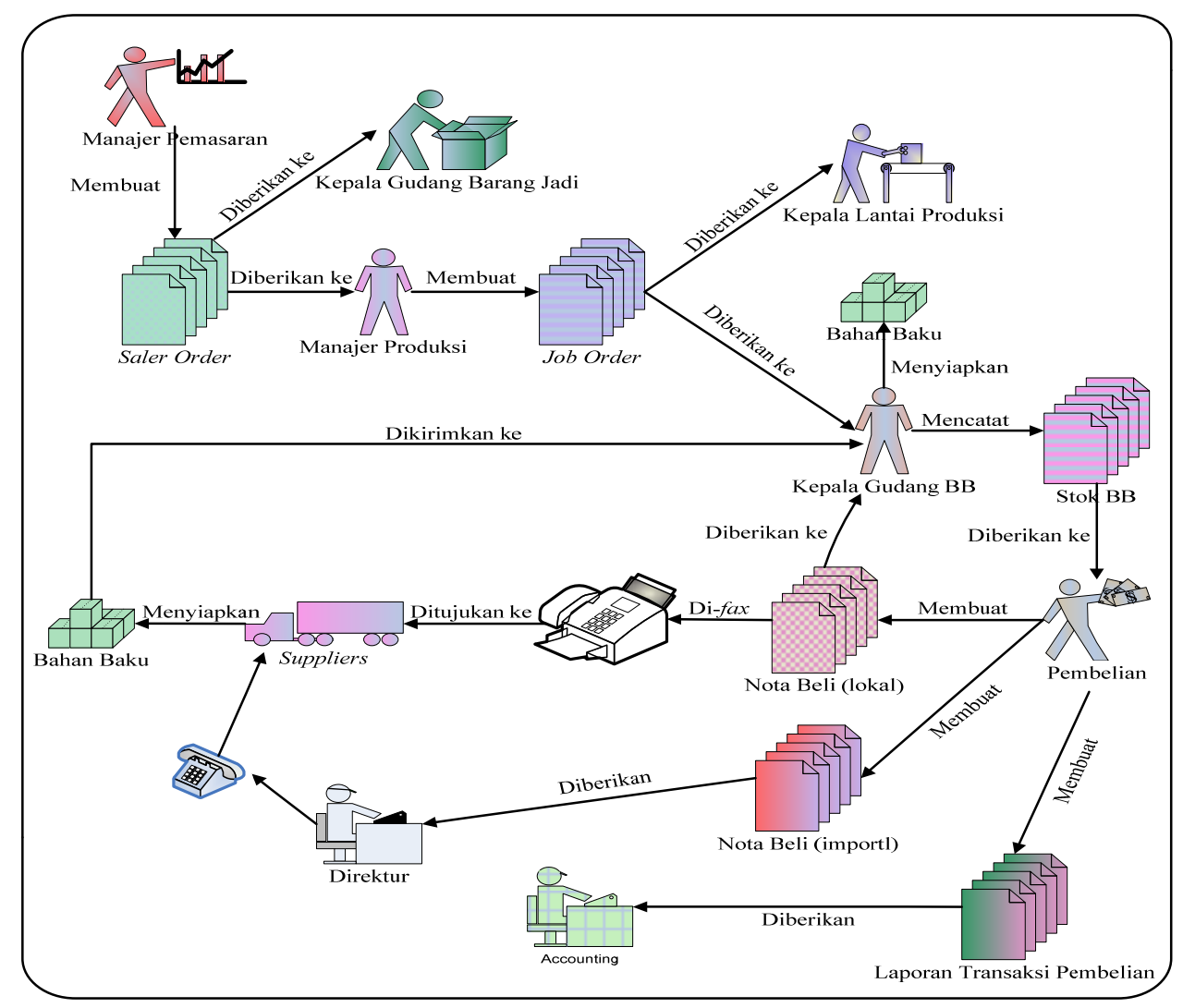

Gambar 2 Rich Picture Sistem yang sedang berjalan

Setiap bulan bagian gudang bahan baku mengirimkan catatan jumlah stok bahan baku kepada bagian pembelian. Dari catatan stok bahan baku tersebut, bagian pembelian kemudian menentukan kapan harus melakukan pemesanan bahan baku dan berapa kuantitas pemesanannya. Penentuan tersebut bukan berdasarkan kepada perhitungan apapun, melainkan hanya berdasar kepada intuisi saja. Kemudian bagian pembelian membuat nota beli yang berisi jenis-jenis bahan baku yang akan dibeli 
beserta kuantitasnya. Untuk pemesanan bahan baku lokal, nota beli yang telah dibuat manajer pembelian langsung dikirim ke supplier melalui mesin fax. Sedangkan untuk bahan baku impor, nota beli diberikan kepada direktur, kemudian direktur yang memesan langsung ke supplier. Selain nota beli, manajer pembelian membuat laporan transaksi pembelian bahan baku dan diberikan ke bagian akunting.

Apabila bahan baku sudah sampai ke gudang, bagian gudang bahan baku akan mencocokkan nota beli dengan surat jalan dari supplier apakah bahan baku yang dikirimkan supplier sesuai dengan bahan baku yang dipesan. Bahan baku yang sudah diperiksa dan sesuai dengan pesanan, kemudian dimasukkan ke dalam gudang bahan baku dan kepala gudang bahan baku melakukan pencatatan stok bahan baku.

\section{Usulan Aplikasi Sistem Peramalan dan Pengadaan Bahan Baku}

Model sistem pemesanan bahan baku ini terdiri dari satu menu utama. Setiap user yang sudah melakukan Login dapat masuk ke sistem sesuai dengan otoritas masing-masing dan melakukan tugasnya. Menu Pesananan terdiri dari satu form pesanan. Form ini hanya dapat dilihat oleh bagian pemasaran yang memiliki tugas untuk memasukkan data pesanan pelanggan ke dalam sistem. Menu Bahan Baku merupakan menu yang terdiri dari lima form. Menu ini dapat diakses bagian gudang bahan baku dan bagian pembelian. Tidak semua form dapat diakses, tetapi hanya beberapa form saja. Sedangkan Form perhitungan peramalan hanya dapat diakses oleh kepala gudang bahan baku yang memiliki tugas untuk melakukan peramalan kebutuhan bahan baku beberapa periode ke depan berdasarkan data historis penggunaan bahan baku.

Selanjutnya Menu Perhitungan dibagi menjadi dua form. Form pertama adalah form Perhitungan Peramalan. Form ini hanya dapat diakses oleh kepala gudang bahan baku yang bertugas untuk melakukan peramalan kebutuhan bahan baku beberapa periode ke depan berdasarkan data historis penggunaan bahan baku. (Gambar 3).

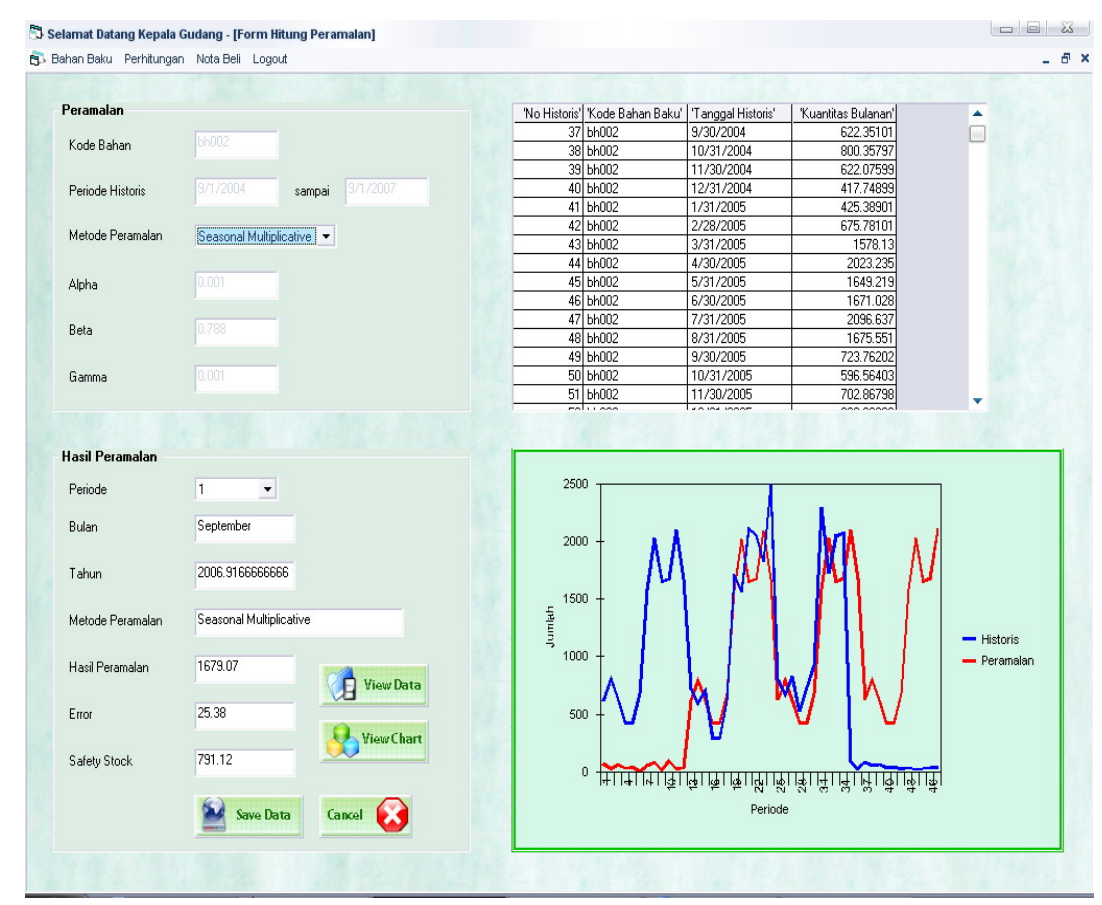

Gambar 3 Form Perhitungan Peramalan 
Bagian pembelian juga memegang peranan penting. Seorang manajer pembelian harus melakukan perhitungan kuantitas pemesanan bahan baku yang tepat. Pemesanan yang tidak tepat, berlebih, atau kurang dapat menyebabkan kerugian bagi perusahaan. Tentunya setiap perusahaan selalu menginginkan keuntungan yang berlipat ganda. Oleh karena itu, penentuan kuantitas pemesanan sebaiknya dihitung dengan menggunakan beberapa metode, dan dipilih metode yang menghasilkan total biaya paling rendah.

Kemudian form kedua adalah form Perhitungan Pemesanan. Form ini hanya dapat diakses oleh manajer pembelian. Manajer pembelian bertugas untuk menghitung kuantitas pemesanan bahan baku yang paling ekonomis dengan membandingkan beberapa metode perhitungan. (Gambar 4)

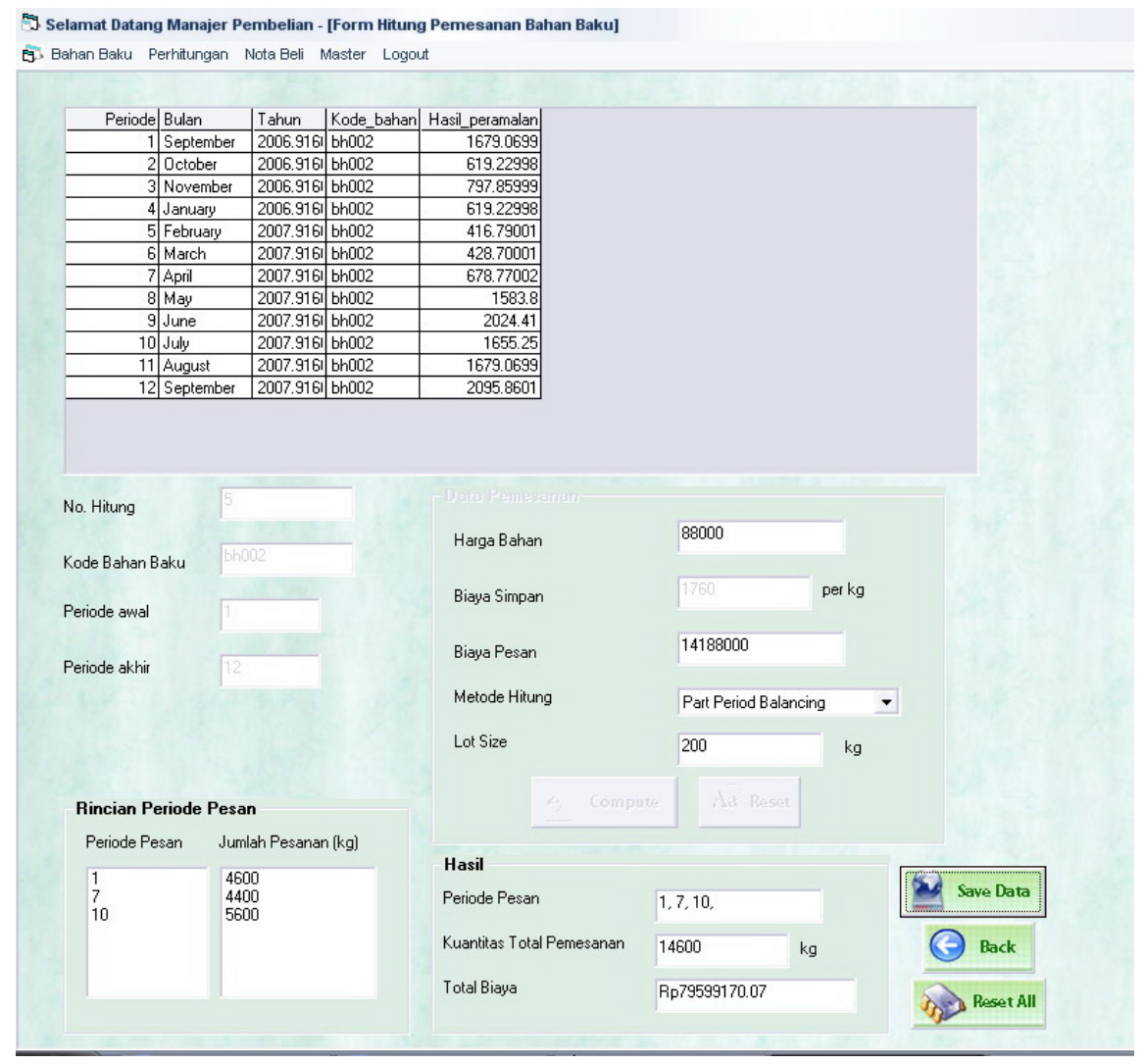

Gambar 4 Form Perhitungan Pemesanan

\section{SIMPULAN}

Sistem dirancang memiliki tujuan dan fungsi untuk pemesanan bahan baku, mulai dari pencatatatan keluar atau masuk, penghitungan peramalan, penghitungan kuantitas pemesanan, hingga pembuatan nota beli untuk tiap jenis bahan baku dengan kuantitas sesuai dengan perhitungan. Bagian gudang bahan baku berperan sangat penting dalam sistem ini. Bagian gudang harus memasukkan data bahan baku yang masuk dan keluar, menghitung pemakaian bahan baku setiap bulannya, menghitung peramalan kebutuhan bahan baku periode mendatang, dan juga mengubah status nota beli apabila bahan baku yang dipesan telah dikirim oleh supplier. 
Dengan adanya sistem pemesanan bahan baku diharapkan dapat meningkatkan akurasi data stok bahan baku. Sebelumnya, pencatatan keluar masuknya bahan baku dilakukan secara manual sehingga sering kali stok fisik tidak sesuai dengan catatan stok. Setelah adanya sistem, maka stok dapat dijaga keakuratan dan kelengkapannya. Sebab, stok bahan baku langsung di-update setelah bahan baku keluar atau bahan baku masuk disimpan dalam database.

Selain itu, sistem juga lebih memudahkan pekerjaan bagian gudang bahan baku. Saat pesanan diterima, sistem sudah melakukan breakdown kebutuhan tiap jenis bahan baku untuk pesanan tersebut. Sehingga saat bagian gudang mengklik nomor pesanan, rincian bahan bakunya langsung ditampilkan dan bahan baku dapat langsung disiapkan. Begitu pula saat bahan baku diterima, bagian gudang cukup melihat nota beli yang dipesan apakah sesuai dengan bahan baku yang diterima. Jadi dengan adanya sistem, efisiensi waktu dapat ditingkatkan karena proses pekerjaan dapat lebih mudah untuk diselesaikan dengan bantuan sistem.

Sistem juga dapat meningkatkan akurasi dan kelengkapan data stok bahan baku serta meningkatkan akurasi peramalan kebutuhan bahan baku berdasarkan data historis. Secara keseluruhan, sistem diharapkan membawa dampak positif dalam hal pengendalian bahan baku dan menjaga stok bahan baku agar berada dalam status dipantau dan terkendali (tidak berlebihan dan tidak kekurangan karena keduanya akan menimbulkan pembengkakan biaya persediaan).

\section{DAFTAR PUSTAKA}

Baroto, T. (2002). Perencanaan dan Pengendalian Produksi. Jakarta: Ghalia Indonesia.

Griffiths, G., \& Payab, H. (2010). Supply chain on the heels of demand: issues of e-procurement. Journal of Global Business, 4(2), 29-35.

Makridakis, S. C., Wheelwright., Victor E., McGee. (1999). Metode dan Aplikasi Peramalan. Edisi Kedua. Jilid 1. Jakarta: Binarupa Aksara.

Mathiassen, L., Munk-Madsen, A., Nielsen, P. A., \& Stage, J. (2000). Object-Oriented Analysis and Design. Marko, Aalborg, Denmark.

Mose, J. M., Njihia, J. M., Magutu, P. O. (2013, May). The critical success factors and challenges in e-procurement adoption among large scale manufacturing firms in Nairobi, Kenya. European Scientific Journal, 9(13), 375-401. Diakses 21 Mei 2014 dari https://profiles.uonbi.ac.ke/njihia/files/the_critical_success_factors_and_challenges_in_eprocurement_adoption_among_large_scale_manufacturing_firms_in_nair

Render, B., Stair, R. M., \& Hanna, M. E. (2003). Quantitative Analysis for Management. $8^{\text {th }}$ Edition. New Jersey: Prentice Hall.

Siswanto. (2007). Operations Research. Jilid 2. Jakarta: Erlangga.

Subramanian, C., \& Shaw, M. J. (2004). The effects of process characteristics on the value B2BEprocurement. Information Technology and Management, 5(1-2), 161-180.

Vaidya, K., Sajeev, A. S. M., \& Callender, G. (2006). Critical factors that influence e-procurement implementation success in the public sector. Journal of Public Procurement, 6(1\&3), 70-99. Diakses 23 Mei 2014 dari http://ippa.org/jopp/download/vol6/issue-12/e_ProSympAr6_Vaidya_etal.pdf. 